performance of a song from the student's educational repertoire. At the same time, advanced mastering of other vocal-performing techniques by senior students under the condition of their vocal-performing readiness for this is also an urgent task of a teacher of pop singing of higher education institutions.

\title{
References:
}

1. Carter H. Vocal Warm-ups and Vocalises. Huntington Beach, CA.: Goldenwest College Publication, 2003. 214 p.

2. Linklater K. Freeing the Natural Voice. New York: Drama Book Specialists, 1976. 254 p.

3. Riggs S. Singing for the Stars: A Complete Program for Training Your Voice. Los Angeles, CA: Alfred Publishing Co., Inc, 1998. 168 p.

4. Sadolin C. Complete Vocal Technique. Denmark, 2000. 255 p.

DOI https://doi.org/10.30525/978-9934-26-004-9-96

\section{ПРОФЕСІЙНЕ ДЕКОРАТИВНЕ МИСТЕЦТВО УКРАЇНИ: ТЕНДЕНЦІЇ РОЗВИТКУ В УМОВАХ СВІТОВИХ ГЛОБАЛІЗАЦІЙНИХ ПРОЦЕСІВ (КЕРАМІКА, СКЛО, ДЕРЕВО, ТЕКСТИЛЬ)}

\author{
Чегусова 3. A. \\ заслужений діяч мистецтв Украӥни, \\ науковий співробітник відділу образотворчого \\ і декоративно-прикладного мистеитва \\ Інституту мистецтвознавства, фольклористики та етнології \\ імені М. Т. Рильського Начіональної академії наук Украӥни \\ м. Київ, Україна
}

У науковій доповіді розкриваються особливості розвитку професійного декоративного мистецтва України в умовах світових глобалізаційних процесів, висвітлюється його роль у формуванні такого визначного чинника як національно-культурна ідентичність українського народу у діючих парадигмах нової реальності суспільства.

Проблематика української національно-культурної ідентичності $\epsilon$ предметом дослідження числених вітчизняних вчених-гуманітарієв, 3-поміж яких В. Андрущенко, I. Бех, В. Воронкова, В. Горський, К. Журба, М. Козловець, С. Кримський, М. Михальченко, Р. Поліщук, М. Попович, М. Розумовський, Н. Скрицька, В. Табачковський, О. Титар, Д. Шевчук, В. Шейко та ін. 
В аспекті проблематики професійного декоративного мистецтва і під кутом зору національно-культурної ідентифікації в умовах глобалізаційних процесів в Україні такий аспект у мистецтвознавчій науці розглядається вперше: дослідження проблем, пов'язаних 3 поняттями «національна ідентичність», «культурна ідентичність», «українська ідентичність», традиційно вважалося прерогативою гуманітаристики - філософії, педагогіки, етнології, культурології, психології, соціології, але не мистецтвознавства.

Глобалізаційні процеси, що відбуваються у цивілізації , звісно, ставлять перед культурою і мистецтвом певні виклики. Дана стадія так званого «інформаційного суспільства» вирізняється певними культурними суперечностями між західними формами масової культури та традиційними цінностями не західних народів, наявними протиріччями між суспільством масового споживання i базовими соціокультурними ментально-ціннісними засадами слов'янських народів. Йде глобальна боротьба за культурно-духовний та інформаційний простір. Тому національна визначеність культури в суспільстві i особливо мистецтва в таких умовах має вкрай важливе значення.

На зламі тисячоліть пильну увагу в загальному мистецькому процесі привертають художники, що працюють в ділянці професійного декоративного мистецтва: кераміці, склі, художній обробці дерева, текстилі, передусім, завдяки активізації їхніх пошуків нестандартних підходів до матеріалу, які неминуче призводять до трансформації звичайної декоративної образності. Важливим фактором $є$ наявний прояв українськими професійними майстрами декоративного мистецтва національного коріння, усвідомлення кожним своєї причетності до своєрідності вітчизняної культури. Разом з тим їхні твори цікаві намаганням як по-новому осмислити i творчо трансформувати національні традиції, так i осягнути світові тенденції. Сучасне професійне декоративне мистецтво, хоча й іде своїм шляхом, відмінним від народного мистецтва, але опановує його історію і використовує його символіку. Уважне ставлення до народного мистецтва як до феноменального вияву національної духовної культури співіснує 3 відкритістю до європейських і світових мистецьких досягнень.

У 1990-х-2010-х рр. в царині професійної кераміки активно працюють такі видатні київські майстри старшого покоління як О. Рапай, О. Грудзинська, Г. Севрук, П. Печорний, Н. Ісупова, О. Міловзоров; уславлені львівські митці Т. Левків, 3. Береза, Р. Петрук, У. Ярошевич, Я. Мотика, О. Безпалків, Г. Ошуркевич; талановиті художники середньої генерації з Києва Л. Богинський, А. Скорий, М. Галенко, Н. та С. Козаки, В. Томашевська, Л. Красюк, А. Ільїнський, Г. Семенко, Б. Данилов, Г. Міміношвілі, О. Бланк, М. Лампека, В. Онищенко; неординарні 
мистецькі особистості зі Львова - I. та Л. Ковалевичи, С. Андрусів, Г.- О. Липа, Г. Лисик, Т. Береза, І. Береза, Г. Друль, Т. Павлишин-Святун, В. Боднарчук; провідні керамісти з Полтави - С. Пасічна, з Харкова - П. Мось, з Сум - В. Єрмоленко, Г. Протасов; з Черкас - М. Теліженко, I. Фізер, Л. Шилімова-Ганзенко; 3 Ужгорода - М. Росул, В. Віньковський, Я. Борецький, Н. Грабар-Борецька; з Одеси - Н. Федорова, О. Дмитрієв; 3 Вінниці - В. Оврах; 3 Луцька - В. Хижинський, 3 Донецьку - Г. та І. Васильєви, Г. та В. Беро, які використовують найдавніші загальнолюдські символи, що стали основою традиційного народного мистецтва 3 його характерним підходом до твору, як до певної закодованої знакової системи, що має нести в собі нашарування загальнолюдського досвіду. Вже на початку своєї творчої діяльності кожний $з$ них тяжів до першооснов і джерел національної культури, народного мистецтва, яке, тим не менш, ніколи не було для них предметом імітації чи копіювання.

Левова частка досягнень у царині мистецтва художнього скла України на межі XX - XXI ст. ст. належить переважно художникамсклярам самобутньої львівської школи декоративно-прикладного мистецтва, що формувалась на багатих традиціях народного мистецтва цього краю, всотуючи як надбання національної культури, так i досягнення європейських професіональних митців. Цілком справедливим сприймається твердження, що «...львівське художнє скло - на кшталт венеційського Мурано, й немає шкали, щоб визначити - яке з них якісно вище: і перше, i друге зближують крила традицій». [1, с. 89]

У 1990-2000-х рр. скло - «мистецтво вогню і світла» - втілюється у новітніх неординарних формах такими талановитими українськими митцями як А. Бокотей, Ф. Черняк, Р. Петрук, О. Звір, Б. Васильців, Р. Дмитрик, О. Принада, А. Петровський, А. Курило, О. Шевченко, I. Мацієвський, С. Кадочников, А. Гоголь: ними створюються численні раритети в матеріалах гутного скла і матованого кришталю, де поступово стираються межі між ужитковим предметом і склопластикою, скульптурою і вжитковим мистецтвом. I вже на початку XXI століття гутництво, розвиваючись в контексті авторського студійного скла, отримує світове визнання, яскраво доводячи, що українське художнє скло за спадковістю традицій, багатоманітністю образно-пластичних рішень та вишуканістю декорування - $є$ «виняткове явище, яке охоплює творчість плеяди видатних народних майстрів та професійних художників» [2, с. 3].

Дерево - як одне $з$ найдавніших й найближчих до людського єства матеріалів 3 глибокими смисловими резонансами в колективній свідомості, століттями слугувало українському народу універсальним засобом мистецького вислову. За плечима таких знаних професійних 106 
художників як І. Стеф’юк, І. Фізер, М. Малишко, Р. Петрук, В. Іванишин, В. Андрушко, В. Вороняк, В. Хомик, М. Вертуозов, які на зламі XX-XXI ст. творчо працюють 3 деревом в таких жанрах як рельєфне різьблення у формах настінних панно, декоративна скульптура, об'ємнопросторова пластика, стоїть не одне покоління народних майстрів.

Для сучасного гобелена як жанру декоративного мистецтва народний текстиль в добу глобалізації є своєрідною матрицею з власною програмою ткацтва і як техніки, і як композиційної структури, що наділена своїми принципами організації ритму, кольору, орнаменту. Це доводять твори таких високопрофесійних майстрів ткання 3 різних міст України як Л. Жоголь, І. та М. Литовченки, В. Федько, Н. Борисенко, Н. Лапчик, М. Базак, Н. Дяченко-Забашта, О. Куца, Л. Майданець-Саєнко (Баргилевич) (Київ), С. Фащенко, С. Шабатура, Н. Паук, О. Крип'якевич, I. Вінницька, О. Риботицька, О. Парута-Вітрук, Т. Печенюк, В. Ганкевич, С. Бабков, Л. Гошовський, Г. Кусько, З. Шульга, М. Шеремета (Львів), М. Білас (Трускавець), О. Ковальчук (Вінниця), які $є$ вихованцями Львівського державного інституту прикладного i декоративного мистецтва, а згодом Львівської національної академії мистецтв i, відповідно, вони залишаються носіями традицій славетної львівської мистецької школи з ії увиразненим вектором етнічної і національної ідентичності.

Так професійне декоративне мистецтво України в добу глобалізації сприймається як потужна галузь у сфері культури 3 притаманними їй ознаками автентичної духовної генетики, як динамічна рівновага тисячолітніх традицій і сучасної образотворчості. Глобалізація, як це не парадоксально, породжує і зворотній процес, а саме - підштовхує українське мистецтво до національної ідентифікації, спрямовує до пошуків архетипів своєї культури, повертає до національної культурної спадщини стимулює збереження національної самобутності. Творчість митців, які працюють в різних ділянках українського професійного декоративного мистецтва в добу глобалізації мають величезне значення у поверненні українців до духовних цінностей, у їхньому естетичному вихованні, у формуванні духовних засад «глобалізованої людини» i, головне, у формуванні національно-культурної ідентичності.

\section{Література:}

1. Федорук О. Маестро художнього скла Андрій Бокотей. Київ : Либідь, 2008. 320 с.

2. Черняк Ф. Львівське гутне скло другої половини XX століття / Нарис історії : навчальний посібник для студентів вищих мистецьких навчальних закладів. Львів: ЛНАМ, 2006. 164 с. 